\title{
Saccharomyces rosinii sp. nov., a New Species of Saccharomyces Sensu Lato (van der Walt)
}

\author{
ANN VAUGHAN-MARTINI,* STEFANIA BARCACCIA, \\ AND PAOLA POLLACCI \\ Industrial Yeasts Collection, Sezione Microbiologia Applicata, Dipartimento \\ di Biologia Vegetale, Università degli Studi, Perugia, Italy
}

\begin{abstract}
Strains of the phenotypically similar species Saccharomyces castellii, Saccharomyces dairensis, and Saccharomyces transvaalensis, recently separated on the basis of DNA base sequence homologies and electrophoretic karyotypes, have been reexamined by techniques of conventional taxonomy. While the limited physiological differences observed are somewhat restrictive for species distinction, it is possible to separate some of these taxa by using a minimal number of macromolecular and phenotypic criteria. Two strains formally classified as $S$. dairensis constitute a new species since, while having minimal nucleotide base sequence homology with the other species, they were found to have a 97\% DNA-DNA reassociation rate with each other. This species is described as Saccharomyces rosinii in honor of Gianfranco Rosini, late professor of enology and microbiology of the University of Perugia, Perugia, Italy.
\end{abstract}

Strains belonging to the taxa Saccharomyces castellii (3) and Saccharomyces dairensis (8), as well as to the recently reinstated species Saccharomyces transvaalensis $(12,22)$, are characterized by a very limited utilization of those carbon and nitrogen sources (assimilative and/or fermentative) normally tested in conventional yeast taxonomy. Classification within this subgroup of Saccharomyces sensu lato (13) has undergone several reevaluations as the criteria used for species designations were amplified and the number of described strains increased $(5,7,11,14,19,23)$. A review of the history of this species complex can be found in a recent study (17).

From the beginning of the 1960 s the advent of molecular taxonomy brought to light the shortcomings of many species designations. While techniques such as in vitro DNA-DNA hybridization can compare all expressed and nonexpressed characters of an organism in a single experiment $(6,9)$, tests using conventional classifications consider only a minimal portion of the genome. As a result, there began a general trend in which many species separations, particularly those which had been established on the basis of minimal phenotypic differences, were critically evaluated. Accordingly, several taxa were brought into synonymy and the number of accepted species was greatly reduced $(1,4)$. The genus Saccharomyces is a perfect example of that tendency, having gone from 21 species in the second edition of the monograph The Yeasts-A Taxonomic Study (13) to 9 in the third edition (23). At that time the species $S$. castellii was reduced to synonymy with the older, phenotypically similar taxon $S$. dairensis (23).

In spite of the basic correctness of these actions, studies of DNA base sequence similarities within the genus Saccharomyces $(2,10,17-20)$ demonstrated that nearly identical phenotypic profiles do not always correspond to synonymy on the genomic level. Likewise, three separate studies of DNA-DNA reassociation kinetics $(17,19,21)$, together with two investigations studying morphology and sexual reactions between strains of Saccharomyces sensu lato $(15,22)$, demonstrated that the taxa $S$. castellii, $S$. dairensis, and $S$. transvaalensis are dis-

\footnotetext{
* Corresponding author. Mailing address: Dipartimento di Biologia Vegetale, Sezione Microbiologia Applicata, Borgo XX Giugno, 74, Perugia, 06121, Italy. Phone: 3975 5856479. Fax: 39755856470. Electronic mail address: martinal@unipg.it.
}

tinct. In those studies, it was also shown that several strains classified into one of the three species do not correspond to the original designation.

In light of the new interspecific relationships established as a result of those studies, it was decided to reevaluate the same strains by using conventional taxonomic criteria. The scope of this investigation was to determine if it is possible to distinguish the taxa on a nonmolecular level.

As expected, the results of physiological analyses (Table 1), determined in liquid medium on a roller drum at $25^{\circ} \mathrm{C}$ by methods described by van der Walt and Yarrow (16), confirmed the difficulty of establishing species boundaries between these taxa, characterized by very limited responses to most tests. Nevertheless, when these data are considered together with those obtained from DNA-DNA hybridization and electrophoretic karyotype determinations $(17,19,21)$, it is possible, with some difficulty, to separate most of the species. The most discernible is a pair of separate, genetically homologous strains, $6747^{\mathrm{T}}$ ( $\mathrm{T}$ indicates type strain) and 6750, which do not assimilate trehalose, D-ribose, D-glucitol, or succinate. In addition, a maximum growth temperature of $28^{\circ} \mathrm{C}$ should be sufficient to distinguish this taxon from the other species studied. For the most part only strains homologous to the type strain of $S$. castellii $(17,19,21)$ are able to grow on D-ribose as a sole carbon source. Nevertheless, the fact that two of the nine strains of the group gave a negative response while one strain of the $S$. dairensis complex is able to utilize this pentose limits the usefulness of this character for the distinction of these species. The assimilation of succinate presents the same difficulties, since it is mostly positive for strains of $S$. dairensis and positive for two-thirds of those close to $S$. castellii. The two strains of $S$. transvaalensis also have limited physiological differences from both $S$. castellii and $S$. dairensis and are really distinguishable only when the results of previous studies considering ascospore ultrastructure $(15,22)$ and DNA base sequence homologies and electrophoretic karyotypes (17) are considered. Distinction of strains 6357, 6359, and 6752, which have been shown to have DNA base sequences different from those of all of the other strains (17), is not possible on the basis of the results of this study. It will be interesting to see if other techniques of molecular analysis which consider specific regions of rRNA or genes coding for rRNA could be useful for discriminating these separate species. Until such time, these 
TABLE 1. Discriminating characteristics of $S$. dairensis and related species

\begin{tabular}{|c|c|c|c|c|c|c|c|c|c|}
\hline \multirow{2}{*}{$\begin{array}{l}\text { Species and DBVPG } \\
\text { designation }^{a}\end{array}$} & \multicolumn{4}{|c|}{ Carbon assimilation ${ }^{b}$ of: } & \multirow{2}{*}{$\begin{array}{c}T_{\max }{ }^{c} \\
\left({ }^{\circ} \mathrm{C}\right)\end{array}$} & \multicolumn{2}{|c|}{${\mathrm{DNA} / \mathrm{DNA}^{d}}$} & \multirow{2}{*}{ Ascus/ascospores } & \multirow{2}{*}{$\begin{array}{c}\text { Electrophoretic } \\
\text { karyotype } \\
\text { (no. of bands/ } \\
\text { size range }[\mathrm{kb}] \text { ) }\end{array}$} \\
\hline & TRE & RIB & D-GLU & ASU & & $6366^{\mathrm{T}}$ & $6747^{\mathrm{T}}$ & & \\
\hline \multicolumn{10}{|l|}{ S. castellii } \\
\hline $6298^{\mathrm{T}}$ & $+w$ & $+\mathrm{w}$ & + & + & 35 & 35 & 30 & Round, oval/1-2 thick walled & $11 / 3,000-600$ \\
\hline 6352 & $+\mathrm{s}$ & $+w$ & + & + & 32 & 30 & - & Round, oval/1-2 thick walled & $8 / 3,000-650$ \\
\hline 6353 & $+w$ & $+\mathrm{w}$ & + & $+w$ & 32 & 27 & - & Round, oval/1-2 thick walled & $8 / 3,000-650$ \\
\hline 6356 & - & $+w$ & + & - & 32 & 25 & - & Round, oval/1-2 thick walled & $7 / 3,000-650$ \\
\hline 6361 & $+s$ & $+\mathrm{w}$ & + & + & 40 & 30 & - & Round, oval/1-2 thick walled & $9 / 3,000-600$ \\
\hline 6410 & + & + & + & + & 32 & 37 & - & Round, oval/1-2 thick walled & $10 / 3,000-600$ \\
\hline 6751 & $+w$ & - & + & + & 35 & - & - & Round, oval/1-2 thick walled & $8 / 3,000-600$ \\
\hline 6759 & + & $+\mathrm{s}$ & + & - & 37 & 29 & 47 & Round, oval/1-2 thick walled & $15 / 2,200-500$ \\
\hline 6758 & + & - & $+\mathrm{s}$ & - & 37 & - & - & Round, oval/1-2 thick walled & $8 / 2,500-500$ \\
\hline \multicolumn{10}{|l|}{$\begin{array}{l}S . \text { dairensis and } \\
\text { related strains }\end{array}$} \\
\hline 6357 & $+s$ & + & - & - & 37 & 9 & 37 & Not observed & $8 / 2,200-600$ \\
\hline 6359 & $+\mathrm{w}$ & - & + & $+w$ & 37 & 32 & 40 & Not observed & $8 / 2,200-600$ \\
\hline $6366^{\mathrm{T}}$ & - & - & + & + & 35 & $(100)$ & 6 & Round, oval/1-2 thick walled & $7 / 2,200-750$ \\
\hline 6752 & + & - & + & $+\mathbf{s}$ & 35 & 34 & 20 & Not observed & $10 / 2,200-750$ \\
\hline \multicolumn{10}{|l|}{ S. rosinii } \\
\hline $6747^{\mathrm{T}}$ & - & - & - & - & 28 & 6 & $(100)$ & Oval, elongate/1-2 thick walled & $10 / 2,200-500$ \\
\hline 6750 & - & - & - & - & 28 & 8 & 97 & Oval, elongate $/ 1-2$ thick walled & $10 / 2,200-500$ \\
\hline \multicolumn{10}{|l|}{ S. transvaalensis } \\
\hline 6756 & + & - & $+w$ & $+w$ & 37 & 60 & 23 & $\begin{array}{l}\text { Round, oval/1-2 thick walled } \\
\text { with ciliz } f\end{array}$ & $9 / 2,200-370$ \\
\hline $6757^{\mathrm{T}}$ & + & - & $+\mathrm{s}$ & - & 37 & 59 & & $\begin{array}{l}\text { Round, oval/1-2 thick walled } \\
\text { refringent } t^{f g}\end{array}$ & $9 / 2,200-500$ \\
\hline
\end{tabular}

${ }^{a}$ Strains are arranged according to the relationships revealed by DNA base sequence relatedness (17). T, type strain of the epithet; DBVPG, Industrial Yeasts Collection, Sez. Microbiologia Applicata, Dipartimento di Biologia Vegetale, Università degli Studi di Perugia, Perugia, Italy.

${ }^{b}$ TRE, trehalose; RIB, D-ribose; D-GLU, D-glucitol; ASU, Succinate; +, assimilation; -, no assimilation; w, weak; s, slow.

${ }^{c} T_{\text {max }}$, maximum growth temperature (tested at $2{ }^{\circ} \mathrm{C}$ intervals up until $30^{\circ} \mathrm{C}$ and at $1{ }^{\circ} \mathrm{C}$ intervals above $30^{\circ} \mathrm{C}$ in tubes containing $1 \%$ yeast extract-1\% peptone-2\% glucose equilibrated in a water bath).

${ }^{d}$ DNA/DNA, percent DNA base sequence relatedness; parenthetical values (100) indicate $100 \%$ base sequence homology of a strain with itself. —, not determined.

${ }^{e}$ Vaughan-Martini and Barcaccia (17).

${ }^{f}$ Vaughan-Martini and Pollacci (22).

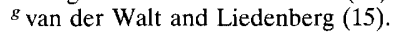

will have to be considered part of a complex with the type strain of $S$. dairensis.

The separate, related strains $6747^{\mathrm{T}}$ and 6750 are also morphologically distinct from the other species. While vegetative cells of $S$. castellii, $S$. dairensis, and $S$. transvaalensis are globose to oval and characterized by multilateral budding $(13,23)$, those of $6747^{\mathrm{T}}$ and 6750 are normally smaller, somewhat elongated ( 3.5 to 5.5 by 2 to $2.5 \mu \mathrm{m}$ ) and form buds at various points of the longitudinal extremes of the cell (Fig. 1a).

Different ascospore morphology has been used in the past as a basis for the separation of some these species and even for the creation of a separate genus for $S$. transvaalensis $(14,15)$. Nevertheless, a recent study using transmission electron microscopy (22) demonstrated that even though strains of $S$. transvaalensis do have very large, highly refringent ascospores, those of $S$. castellii and $S$. dairensis are also relatively thick walled. A sexual state in strains of the separate species represented by strains $6747^{\mathrm{T}}$ and 6750 was also observed in 6-month-old cultures which had been maintained on $1 \%$ yeast extract-1\% peptone- $2 \%$ glucose agar at 20 to $25^{\circ} \mathrm{C}$ (Fig. $1 \mathrm{~b}$ ). These two strains, similar to the other three species, show a predominance of one-spore asci, while asci containing two ascospores were less frequently seen. Spores are globose to spherical (diameter, 2.5 to $3 \mu \mathrm{m}$ ) with a morphology very similar to that seen for $S$. castellii and $S$. dairensis $(15,22)$.

Formal species description: Saccharomyces rosinii sp. nov. Vaughan-Martini, Barcaccia et Pollacci. In medio liquido cum glucoso et peptono et extracto levedinis (post dies $3,25^{\circ} \mathrm{C}$ ) cellulae ovoideae, 3.5 - ad $5.5-\mathrm{mm}$ longae et 1.5 ad 2.5 latae, singulae aut binae.

Cultura in agaro peptonato cum glucoso et extracto levedinis (post unum mensem, $25^{\circ} \mathrm{C}$ ) butyrosa, glabra, nitida, et eburnea. Pseudohyphae nullae.

Asci formantur ex transformatione cellularum vegetarum diploidearum (post sextum mensem, 20 ad $25^{\circ} \mathrm{C}$ ). Ascosporae rotundae; una usque ad quatuor in asco.

Glucosum et galactosum fermentantur at non sucrosum, maltosum, lactosum, raffinosum, trehalosum, nec melibiosum.

Glucosum et galactosum assimilantur at non sorbosum, maltosum, cellobiosum, lactosum, melibiosum, raffinosum, melezitosum, xylosum, L-arabinosum, D-arabinosum, D-ribosum, L-rhamnosum, alcohol ethylicum, glycerinum, erythritolum, adonitolum, dulcitolum, D-glucitolum, $\alpha$-methylum-D-glucosidum, salicinum, acidum lacticum, acidum succinicum, acidum citricum, inositolum, acidum malicum, metanolum, $N$-acetylglucosaminum, ethyl-acetatum, et D-glucosaminum.

Nitras kalicus, lysinum, cadaverinum, nec ethylaminum non assimilatur.

Ad crescentiam vitaminae necessariae sunt.

Temperatura maxima crescentiae $28^{\circ} \mathrm{C}$.

Non crescere potest in $10 \% \mathrm{NaCl}-5 \%$ glucoso nec cycloheximido (0.1 g/litrum).

Typus depositus in collectione Centraalbureau voor Schimmelcultures, Delphi, Nederlandia (CBS 7127), et Collezione dei Lieviti Industriali, Perusia, Italia (DBVPG 6747).

On morphology agar, after $48 \mathrm{~h}$ of growth at $25^{\circ} \mathrm{C}$, the cells 

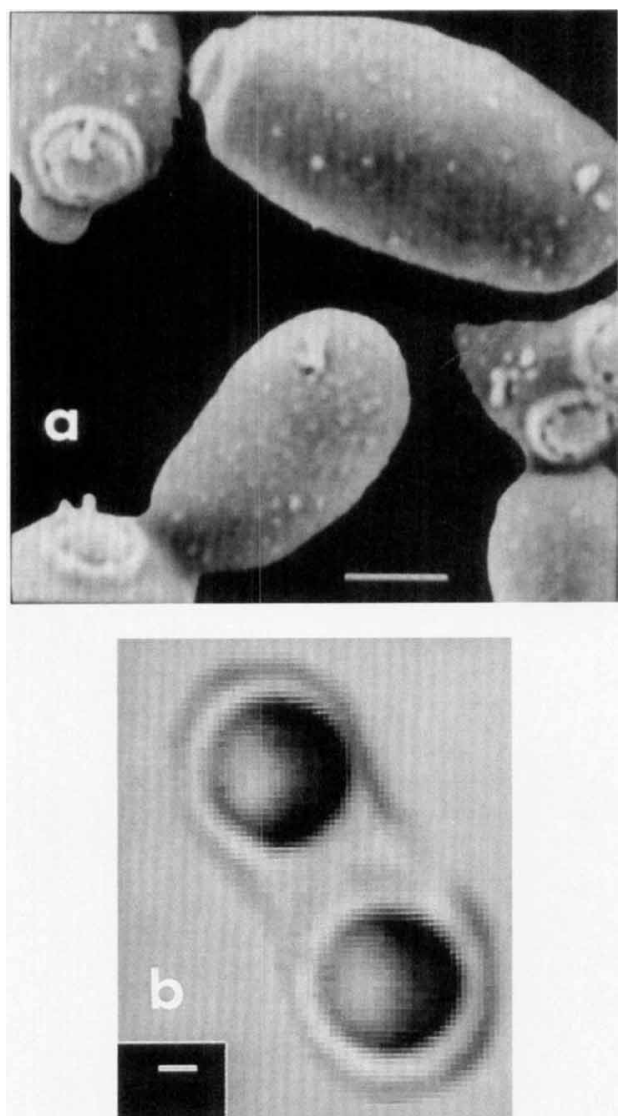

FIG. 1. S. rosinii DBVPG 6747. (a) Vegetative cells; (b) sporulated cells. (a) Sample preparation of 4-day cultures was achieved by fixing in $6 \%$ glyceraldehyde for $16 \mathrm{~h}$ followed by dehydration in 2-ethoxyethanol and $100 \%$ acetone. Samples were then frozen in $\mathrm{CO}_{2}$ and observed by scanning electron microscopy Bar $=1 \mu \mathrm{m}$. (b) Six-month-old culture on $1 \%$ yeast extract-1\% peptone-2\% glucose agar, 20 to $25^{\circ} \mathrm{C}$. Bar $=3 \mu \mathrm{m}$.

are ovoid or elongate, 3.5 to 5.5 by 1.5 to $2.5 \mu \mathrm{m}$, single or in pairs. Budding is at various points of the longitudinal extremes of the cell.

After 1 month at $20^{\circ} \mathrm{C}$, on glucose-peptone-yeast extract agar the streak is butyrous, smooth, glistening, and cream colored.

No pseudohyphae were observed in slide cultures on cornmeal agar, potato agar, and morphology agar.

Asci of elongated form containing one or occasionally two to four globose ascospores (diameter, $3 \mu \mathrm{m}$ ) were observed after 6 months at 20 to $25^{\circ} \mathrm{C}$ on yeast extract-peptone-glucose agar.

Fermented glucose and galactose. Did not ferment sucrose, maltose, lactose, raffinose, trehalose, or melibiose.

Assimilated glucose and galactose. Did not assimilate Larabinose, D-arabinose, salicin, DL-lactate, L-sorbose, sucrose, maltose, cellobiose, trehalose, melibiose, raffinose, melezitose, D-xylose, D-ribose, L-rhamnose, ethanol, glycerol, erythritol, ribitol, galactitol, D-glucitol, $\alpha$-methyl-D-glucoside, succinate, citrate, inositol, malate, hexadecane, methanol, ethyl acetate, $N$-acetyl glucosamine, or D-gluconate.

Did not assimilate cadaverine $\cdot \mathrm{HCl}$, lysine, ethylamine $\mathrm{HCl}$, and $\mathrm{KNO}_{3}$. No growth in 100-ppm cycloheximide, on $10 \%$ (wt $/ \mathrm{wt}$ ) $\mathrm{NaCl}-5 \%$ glucose agar, at $30^{\circ} \mathrm{C}$, or in vitamin-free medium. Growth at $28^{\circ} \mathrm{C}$.

Cultures of the type strain have been deposited in the collections of the Centraalbureau voor Schimmelcultures, Delft,
The Netherlands (CBS 7127), and Collezione dei Lieviti Industriali, Perugia, Italy (DBVPG 6747).

Key to species associated with $S$. dairensis (Naganishi)

1. a. Maximum growth temperature greater than $30^{\circ} \mathrm{C} \ldots \ldots . . .2$

b. Maximum growth temperature below $30^{\circ} \mathrm{C}$ S. rosinii

2. a. Assimilation of sucrose, maltose, and ethanol as sole carbon sources

Saccharomyces sensu stricto

b. Sucrose, maltose, and ethanol not assimilated .3

3. a. D-Ribose not assimilated; growth at $37^{\circ} \mathrm{C}$; one, occasionally two, very large, highly refringent ascospores; electrophoretic karyotype, nine bands, 2,200 to $\sim 400 \mathrm{~kb}$

\section{$S$. transvaalensis}

b. D-Ribose normally not assimilated; growth at 35 to $37^{\circ} \mathrm{C}$; electrophoretic karyotype, 7 to 10 bands, 2,200 to $\sim 600 \mathrm{~kb}$

S. dairensis

c. D-Ribose normally assimilated, growth at 32 to $40^{\circ} \mathrm{C}$; electrophoretic karyotype, 8 to 15 bands, 3,100 to $\sim 500 \mathrm{~kb}$

S. castellii

We express our gratitude to Marjolein van der Horst of the Centraalbureau voor Schimmelcultures, Baarn, The Netherlands, for kindly supplying the photomicrographs of vegetative cells.

This study was supported by a grant from the Italian National Council for Research, Special project RAISA, Subproject 4 (manuscript no. 2390).

\section{REFERENCES}

1. Barnett, J. A., R. W. Payne, and D. Yarrow. 1990. Yeast: characteristics and identification, 2nd ed. Cambridge University Press, Cambridge.

2. Bicknell, J. N., and H. C. Douglas. 1970. Nucleic acid homologies among species of Saccharomyces. J. Bacteriol. 101:505-512.

3. Capriotti, A. 1966. Saccharomyces castellii n. sp.: una nuova specie di lievito isolata da un terreno della Finlandia. Ann. Fac. Agras. Sassari 14:453458.

4. Kreger-van Rij, N. J. W. (ed.). 1984. The yeasts: a taxonomic study, 3rd ed. Elsevier Science Publishers B.V., Amsterdam.

5. Kudriavzev, V. I. 1960. Die systematik der Hefen. Akademic Verlag, Berlin

6. Kurtzman, C. P., and H. J. Phaff. 1987. Molecular taxonomy, p. 63-94. In A. H. Rose and J. S. Harrison (ed.), The yeasts: biology of yeasts, vol. 1. Academic Press, New York.

7. Lodder, J., and N. J. W. Kreger-van Rij. 1952. The yeasts-a taxonomic study. North-Holland, Amsterdam.

8. Naganishi, H. 1917. Three new species of yeasts. Bot. Mag. Tokyo 31:107115.

9. Price, C. W., G. B. Fuson, and H. J. Phaff. 1978. Genome comparison in yeast systematics: delimitation of species within the genera Schwanniomyces, Saccharomyces, Debaryomyces, and Pichia. Microbiol. Rev. 42:161-193.

10. Rosini, G., F. Federici, A. E. Vaughan, and A. Martini. 1982. Systematics of the species of the yeast genus Saccharomyces associated with the fermentation industry. Eur. J. Appl. Microbiol. Biotechnol. 15:188-193.

11. Stelling-Dekker, N. M. 1931. Die sporogenen Hefen. Verh. K. Ned. Akad. Wet. Afd. Natuurkd. 28:1-547.

12. van der Walt, J. P. 1956. Saccharomyces transvaalensis nov. spec. A new yeast from soil. Antonic van Leeuwenhoek J. Microbiol. Serol. 22:190-192.

13. van der Walt, J. P. 1970. Saccharomyces emend. Reess, p. 555-718. In J. Lodder (ed.), The yeasts-a taxonomic study, 2nd ed. Elsevier Science Publishers, Amsterdam.

14. van der Walt, J. P. 1978. The genus Pachytichospora gen. nov. Bothalia 12: $563-564$.

15. van der Walt, J. P., and N. V. D. W. Liedenberg. 1973. Agglutinative mating types of Saccharomyces transvaalensis. Antonie van Leeuwenhoek J. Microbiol. Serol. 39:629-633.

16. van der Walt, J. P., and D. Yarrow. 1984. Methods for the isolation, maintenance, classification and identification of yeasts, p. 47-104. In N. J. W. Kreger-van Rij (ed.), The yeasts-a taxonomic study. Elsevier Science Publishers, Amsterdam.

17. Vaughan-Martini, A., and S. Barcaccia. 1996. A reconsideration of species related to Saccharomyces dairensis (Naganishi). Int. J. Syst. Bacteriol. 46: 313-317. 
18. Vaughan-Martini, A., and C. P. Kurtzman. 1985. Deoxyribonucleic acid relatedness among species of the genus Saccharomyces sensu stricto. Int. J. Syst. Bacteriol. 35:508-511.

19. Vaughan-Martini, A., and C. P. Kurtzman. 1988. Deoxyribonucleic acid relatedness among species of Saccharomyces sensu lato. Mycologia 80:241243.

20. Vaughan-Martini, A., and A. Martini. 1987. Three newly delimited species of Saccharomyces sensu stricto. Antonie van Leeuwenhoeck J. Microbiol. Serol. $\mathbf{5 3 : 7 7 - 8 4 ,}$
21. Vaughan-Martini, A., A. Martini, and G. Cardinali. 1993. Electrophoretic karyotyping as a taxonomic tool in the genus Saccharomyces. Antonie van Leeuwenhoek J. Microbiol. Serol. 63:145-156.

22. Vaughan-Martini, A., and P. Pollacci. 1996. Synonymy of the yeast genera Saccharomyces Meyen ex Hansen and Pachytichospora van der Walt. Int. J. Syst. Bacteriol. 46:318-320.

23. Yarrow, D. 1984. Saccharomyces Meyen ex Reess, p. 379-395. In N. J. W. Kreger-van Rij (ed.), The yeasts-a taxonomic study, 3rd ed. Elsevier Science Publishers B.V., Amsterdam. 